\title{
DOLEGLIWOŚCI BÓLOWE ODCINKA SZYJNEGO KRĘGOSŁUPA WŚRÓD STUDENTÓW FIZJOTERAPII
}

\section{CERVICAL SPINE PAIN AMONG STUDENTS OF PHYSIOTHERAPY}

\author{
Martyna Toman', Magdalena Rutkowska², Magdalena Dąbrowska-Galas², Tomasz Król2, Piotr Michalik², \\ Tomasz Michalski²
}

'Koło Naukowe przy Zakładzie Kinezyterapii i Metod Specjalnych Wydziału Nauk o Zdrowiu w Katowicach, Śląski Uniwersytet Medyczny w Katowicach

2ZZakład Kinezyterapii i Metod Specjalnych Wydział Nauk o Zdrowiu w Katowicach, Śląski Uniwersytet Medyczny w Katowicach

DOI: https://doi.org/10.20883/ppnoz.2019.18

\section{STRESZCZENIE}

Wstęp. Bóle kręgosłupa szyjnego są powszechną dolegliwością i dotyczą coraz młodszych osób, w tym studentów fizjoterapii, którzy są narażeni na dodatkowe przeciążenia podczas zajęć wynikających z harmonogramu zajęć oraz praktyk zawodowych.

Cel pracy. Celem pracy była ocena aktywności fizycznej i stopnia niepełnosprawności wynikającego z dolegliwości bólowych szyjnego odcinka kręgosłupa wśród studentów fizjoterapii.

Materiał i metody. Badaniem objęto 116 studentów kierunku fizjoterapii z województwa śląskiego. Jako narzędzie badawcze wykorzystano autorską ankietę, IPAQ oraz NDI.

Wyniki. 88 studentów (76,10\%) zadeklarowało, że doświadczyło w swoim życiu epizodu bólowego odcinka szyjnego kręgosłupa. Na stosowanie zasad ergonomii w pozycji siedzącej wskazało $72,9 \%(n=80)$ badanych, natomiast nie stosowało ich wcale 7,92\% $(n=8)$ badanych. Umiarkowany poziom aktywności fizycznej odnotowano u 49,50\% ( $n=50)$, niski i wysoki odpowiednio 20,79\% ( $n=21)$ i 16,83\% ( $n=17)$. Wśród badanych 51,49\% ( $n=52)$ sklasyfikowanych zostało do łagodnego rodzaju niepełnosprawności wynikającego z dolegliwości bólowych szyjnego odcinka kręgosłupa, wskazując na ból o charakterze przewlekłym i nawracającym $(93,18 \% ; n=82)$, natomiast $6,82 \%(n=6)$ badanych doświadczyło bólu tylko raz w życiu.

Wnioski. Studenci fizjoterapii, u których odnotowano niższy poziom niepełnosprawności, częściej stosowali zasady ergonomii i rzadziej zgłaszali dolegliwości bólowe szyjnego odcinka kręgosłupa.

Słowa kluczowe: ból kręgosłupa, odcinek szyjny, aktywność fizyczna, studenci fizjoterapii.

\section{ABSTRACT}

Introduction. Cervical spine pain is a common disorder concern even young people including students of physiotherapy. They are exposed on extra overloads during classes and apprenticeships.

Aim. Assessment of physical activity among students of Physiotherapy, cervical spine pain characteristic and assessment were used of the degree of disability which was a consequence of cervical spine pain.

Material and methods. The study included 116 students of third year of physiotherapy. The following instruments: author's survey, International Physical Activity Questionnaire (IPAQ) and Neck Disability Index (NDI).

Results. 88 students $(76,10 \%)$ experienced cervical spine pain. $72,9 \%(n=80)$ respondents used rules of ergonomics of a sitting position, 7,92\% $(n=8)$ did not used them. A moderate level of physical activity was recorded in $49.50 \%(n=50)$ respondents, low and high physical activity was assessed in $20.79 \%$ $(n=21)$ and $16.83 \%(n=17)$ respectively. $51.49 \%(n=52)$ were classified to a mild type of disability resulting from pain in the cervical spine, indicating chronic and recurrent pain $(93.18 \%, n=82)$, and $6.82 \%(n=6)$ students experienced pain only once in their life.

Conclusions. Physiotherapy students who had lower levels of disability, more often used the principles of ergonomics and less frequently reported pain in the cervical spine.

Keywords: back pain, cervical spine, physical activity, physiotherapists.

\section{Wstęp}

Bóle kręgosłupa stanowią bardzo powszechną dolegliwość w dzisiejszych czasach i dotykają ludzkość z krajów cywilizowanych [1,2]. Zespołów bólowych kręgosłupa doświadcza coraz większy odsetek populacji i przyjmuje się, że problem ten dotyczy od 60 do 95\% ludzi na całym świecie [2]. Odcinek szyjny kręgosłupa pod względem bolesności znajduje się na drugim miejscu zaraz po odcinku lędźwiowym i dotyczy 30-50\% populacji [3, 4]. Bóle szyi stanowią duży problem epidemiologiczny mający charakter nawrotowy i przewlekły [5]. W życiu człowieka dochodzi do wielu przeciążeń i mikrourazów, które powodują zaburzenia biomechaniczne kręgosłupa, a głównym czynnikiem sprawczym tych zaburzeń może być ustawienie kręgosłupa szyjnego w nienaturalnej pozycji - wysunięcia lub pochylenia głowy do przodu [5, 7]. Bardzo często ból szyi ujawnia się jako zespół napięciowy szyi, gdzie ból w tej okolicy istnieje razem z tkliwością mięśnia czworo- 
bocznego szyi [8]. Dodatkowym czynnikiem wpływającym na pojawienie się dolegliwości w odcinku szyjnym kręgosłupa może być stres [8, 9]. Wśród czynników ryzyka predysponujących do wystąpienia dolegliwości bólowych odcinka szyjnego można także wymienić palenie tytoniu, bóle w odcinku lędźwiowo-krzyżowym czy wcześniejsze objawy bądź urazy z okolic barków lub ramion $[8,4]$. Jeszcze kilka lat temu przyjmowano, że dolegliwości bólowe kręgosłupa dotyczą tylko osób dorosłych i starszych, jednak obecne badania wskazują, że problem dotyczy także osób młodych $[2,6]$. Studenci fizjoterapii należą do grupy narażonej na występowanie tego typu dolegliwości. W trakcie studiów młodzi ludzie zarówno podczas zajęć, jak i praktyk zawodowych na oddziałach szpitalnych, przebywają w wymuszonej pozycji, co związane jest z wykonywaniem zadań z zakresu obowiązków fizjoterapeuty [6].

\section{Cel pracy}

Celem pracy była ocena aktywności fizycznej i stopnia niepełnosprawności oraz analiza czynników wpływających na stopień niepełnosprawności wynikających z dolegliwości bólowych szyjnego odcinka kręgosłupa wśród studentów kierunku fizjoterapia.

\section{Materiał i metody}

Badaniem o charakterze ankietowym objęto 139 studentów studiów stacjonarnych kierunku fizjoterapia. Zgodę na udział wyraziło 130 ankietowanych, z czego 116 studentów (86 kobiet 130 mężczyzn) udzieliło odpowiedzi na wszystkie pytania zawarte w ankiecie. Kryterium włączenia do badań był ból szyjnego odcinka kręgosłupa. Grupę badaną stanowili studenci, którzy doświadczyli przynajmniej raz epizodu bólowego szyjnego odcinka kręgosłupa (88 studentów). Średni wiek badanej grupy wynosił 21,5 $\pm 0,69$ lat.

Narzędziem badawczym była ankieta składająca się z trzech części. Część I zawierała ogólne pytania dotyczące płci, wieku, miejsca zamieszkania i dolegliwości bólowych odcinka szyjnego. Na te pytania odpowiedzi udzielali wszyscy ankietowani. W dalszej części ankiety pytania dotyczyły zasad zachowania ergonomii w czynnościach dnia codziennego, częstości występowania epizodów bólowych odcinka szyjnego, okoliczności pojawienia się tego bólu, wieku pierwszego epizodu bólowego, korzystania z porad lekarza lub fizjoterapeuty w czasie problemów z odcinkiem szyjnym, a także rezygnacji z zajęć z powodu bólu szyi. Część II narzędzia badawczego stanowił Międzynarodowy Kwestionariusz Aktywności Fizycznej (IPAQ-SF), który pozwolił na klasyfikację ankietowanych ze względu na poziom aktywności (wysoki, wystarczający, niewystarczający). Część III stanowił Kwestionariusz Neck
Disability Index (NDI), którego celem była ocena niepełnosprawności wywołanej przez dolegliwości bólowe, klasyfikująca badanych ze względu na uzyskane punkty do grupy: brak niepełnosprawności (0-4 punktów), łagodna (5-14 punktów), umiarkowana (15-24 punktów), ciężka (25-34 punktów) i skrajna niepełnosprawność (35-50 punktów).

Indywidualne wyniki każdego badanego zostały zebrane w arkuszu kalkulacyjnym Excel 2013 i opracowane statystycznie za pomocą programu Statistica 12. Do porównania grup został wykorzystany test U Manna-Whitney'a, natomiast analiza korelacji rang Spearmana została zastosowana do określenia związku pomiędzy analizowanymi zmiennymi. Dla zastosowanych testów statystycz nych przyjęto poziom istotności $p<0,05$.

\section{Wyniki}

Spośród 88 studentów fizjoterapii zadeklarowało, iż doświadczyło w swoim życiu epizodu bólowego odcinka szyjnego kręgosłupa, 28 badanych (23,90\%) nie odczuwało bólu w tym odcinku kręgosłupa. Średni wiek, w którym po raz pierwszy pojawił się ból odcinka szyjnego kręgosłupa, wynosił 18,69 \pm 1,49 lat. Najczęściej ból po raz pierwszy pojawił się w wieku 18-20 lat.

Na stosowanie zasad ergonomii podczas takich czynności jak korzystanie z komputera, telefonu, tabletu, oglądania telewizji, czytania książek czy uczenia się wskazało $90,90 \%(n=80)$ badanych, natomiast zasad ergonomil wcale nie stosowało $9,10 \%(n=8)$ badanych. Analiza Międzynarodowego Kwestionariusza Aktywności Fizycznej wykazała, iż w grupie badanej najwięcej respondentów prezentowało umiarkowany poziom aktywności fizyczne $(56,82 \% ; n=50)$, natomiast niski i wysoki odpowiednio $23,86 \%(n=21)$ i $19,32 \%(n=17)$. Zgodnie z Kwestionariuszem Neck Disability Index najwięcej badanych $(59,10 \% ; n=52)$ zakwalifikowano do łagodnego rodzaju niepełnosprawności, natomiast $40,90 \%(n=36)$ respondentów sklasyfikowanych zostało jako nieposiadających niepełnosprawności wynikającej z dolegliwości bólowych szyjnego odcinka kręgosłupa. Żadna z badanych osób nie uzyskała wyniku klasyfikującego go do niepełnosprawności ciężkiej i skrajnej. Wśród respondentów 93,18\% $(n=82)$ badanych wskazywało na ból o charakterze przewlekłym i nawracającym, natomiast $6,82 \%(n=6)$ badanych doświadczyło bólu w odcinku szyjnym tylko raz w życiu. Ankietowani najczęściej wskazywali, iż dolegliwości bólowe pojawiały się kilka razy w roku $(40,91 \% ; n=36)$ i kilka razy w miesiącu $(36,36 \% ; n=32)$. Na ból występujący kilka razy w tygodniu skarżyło się $15,91 \%(n=14)$ badanych. Dolegliwości bólowe najczęściej pojawiały się pod- 
czas siedzenia (47,24\%; $n=41$ ) oraz podczas stania (17,01\%; $n=15)$. Mniejszy odsetek respondentów wskazał pozycję leżącą (12,33\%; $n=11)$, aktywność fizyczną (12,18\%; $n=11)$ i czynności domowe (9,09\%; $n=8)$. Badani wskazywali m.in., że ból pojawiał się po przebudzeniu, przy palpacji czy przebywaniu w nieruchomych pozycjach. Szczegółową charakterystykę badanych zmiennych przedstawia tabela 1.

Tabela 1. Ogólna charakterystyka badanych

\begin{tabular}{|c|c|c|c|}
\hline & & $n$ & $\%$ \\
\hline \multirow[t]{2}{*}{ Płeć } & kobieta & 67 & 76,14 \\
\hline & mężczyzna & 21 & 23,86 \\
\hline \multirow{5}{*}{$\begin{array}{l}\text { Stosowanie } \\
\text { ergonomii } \\
\text { podczas } \\
\text { siedzenia }\end{array}$} & wcale & 8 & 9,10 \\
\hline & bardzo rzadko & 15 & 17,04 \\
\hline & czasami & 39 & 44,32 \\
\hline & raczej tak & 12 & 13,64 \\
\hline & $\begin{array}{l}\text { zdecydowanie } \\
\text { tak }\end{array}$ & 14 & 15,90 \\
\hline \multirow{3}{*}{$\begin{array}{l}\text { Poziom } \\
\text { aktywności } \\
\text { fizycznej }\end{array}$} & niski & 21 & 23,86 \\
\hline & umiarkowany & 50 & 56,82 \\
\hline & wysoki & 17 & 19,32 \\
\hline \multirow{2}{*}{$\begin{array}{l}\text { Rodzaj } \\
\text { niepełnosprawności } \\
\text { wg NDI }\end{array}$} & brak & 36 & 40,90 \\
\hline & łagodna & 52 & 59,10 \\
\hline \multirow{4}{*}{$\begin{array}{l}\text { Częstość } \\
\text { dolegliwości } \\
\text { bólowych }\end{array}$} & $\begin{array}{c}\text { jednorazowy } \\
\text { epizod }\end{array}$ & 6 & 6,82 \\
\hline & klika razy/w roku & 36 & 40,91 \\
\hline & $\begin{array}{c}\text { kilka razy/w } \\
\text { mies. }\end{array}$ & 32 & 36,36 \\
\hline & kilka razy/w tyg. & 14 & 15,91 \\
\hline
\end{tabular}

Dolegliwości bólowe wśród badanych najczęściej miały charakter bardzo łagodny (48\%), rzadziej dość silny (2\%), natomiast bólu bardzo silnego oraz najgorszego, jaki można sobie wyobrazić, nie doświadczył żaden spośród badanych. W celu złagodzenia dolegliwości bólowych kręgosłupa szyjnego 9,09\% $(n=8)$ badanych skorzystało z pomocy lekarskiej bądź fizjoterapeutycznej, natomiast 2,27\% ( $n=2$ ) studentów zrezygnowało z uczestnictwa w zajęciach wynikających z planów studiów.

W przedstawionych wynikach badań wykazano istotną statystycznie różnicę pomiędzy badanymi w zakresie stosowania zasad ergonomii w trakcie siedzenia, a rodzajem niepełnosprawności ( $p=0,009)$ oraz w zakresie płci, a rodzajem niepełnosprawności $(p=0,0261)$.
Tabela 2. Porównanie badanych w zakresie płci, stosowania zasad ergonomii, poziomu aktywności, a występującej niepełnosprawności określonej w kwestionariuszu NDI

\begin{tabular}{|c|c|c|c|c|c|c|}
\hline & & \multicolumn{5}{|c|}{ Rodzaj niepełnosprawności (NDI) } \\
\hline & & \multicolumn{2}{|c|}{ 1-brak } & \multicolumn{2}{|c|}{2 -łagodna } & \multirow[t]{2}{*}{$\mathrm{p}$} \\
\hline & & $n$ & $\%$ & $n$ & $\%$ & \\
\hline \multirow[t]{2}{*}{ Płeć } & kobieta & 23 & 26,14 & 44 & 50,00 & \multirow{2}{*}{0,0261} \\
\hline & mężczyzna & 13 & 14,77 & 8 & 9,09 & \\
\hline \multirow{5}{*}{$\begin{array}{l}\text { Stosowanie } \\
\text { ergonomii } \\
\text { podczas } \\
\text { siedzenia }\end{array}$} & wcale & 2 & 2,27 & 6 & 6,82 & \multirow{5}{*}{0,009} \\
\hline & bardzo rzadko & 3 & 3,41 & 12 & 13,64 & \\
\hline & czasami & 13 & 14,77 & 26 & 29,55 & \\
\hline & raczej tak & 10 & 11,36 & 2 & 2,27 & \\
\hline & zdecydowanie tak & 36 & 9,09 & 52 & 6,82 & \\
\hline \multirow{3}{*}{$\begin{array}{l}\text { Poziom } \\
\text { aktywności } \\
\text { fizycznej }\end{array}$} & niski & 9 & 10,23 & 12 & 13,64 & \multirow{3}{*}{ ns } \\
\hline & umiarkowany & 23 & 26,14 & 27 & 30,68 & \\
\hline & wysoki & 4 & 4,55 & 13 & 14,77 & \\
\hline
\end{tabular}

Analiza korelacji rang Spearmana wykazała dwie istotne statystycznie zależności. Pierwszą istotną statystycznie ujemną zależność ( $r=-0,286505, p=0,0068$ ) odnotowano pomiędzy częstością stosowania ergonomii w pozycji siedzącej a punktami uzyskanymi w kwestionariuszu NDI (Tabela 3, rycina 1).

Tabela 3. Wyniki korelacji pomiędzy stosowaniem zasad ergonomii a punktami uzyskanymi w kwestionariuszu NDI

\begin{tabular}{|c|c|c|c|c|}
\hline \multirow[t]{2}{*}{$\begin{array}{c}\text { Para } \\
\text { zmiennych }\end{array}$} & \multicolumn{4}{|c|}{$\begin{array}{c}\text { Korelacja porządku rang Spearmana } \\
\text { BD usuwane parami } \\
\text { Oznaczone wsp. korelacji są istotne } \\
\text { z } p<, 05000\end{array}$} \\
\hline & $\mathrm{N}$ & $R$ & $t(N-2)$ & $p$ \\
\hline $\begin{array}{l}\text { Ergonomia } \\
\text { poz. siedzącej/NDI }\end{array}$ & 88 & $-0,286505$ & $-2,77319$ & 0,0068 \\
\hline
\end{tabular}

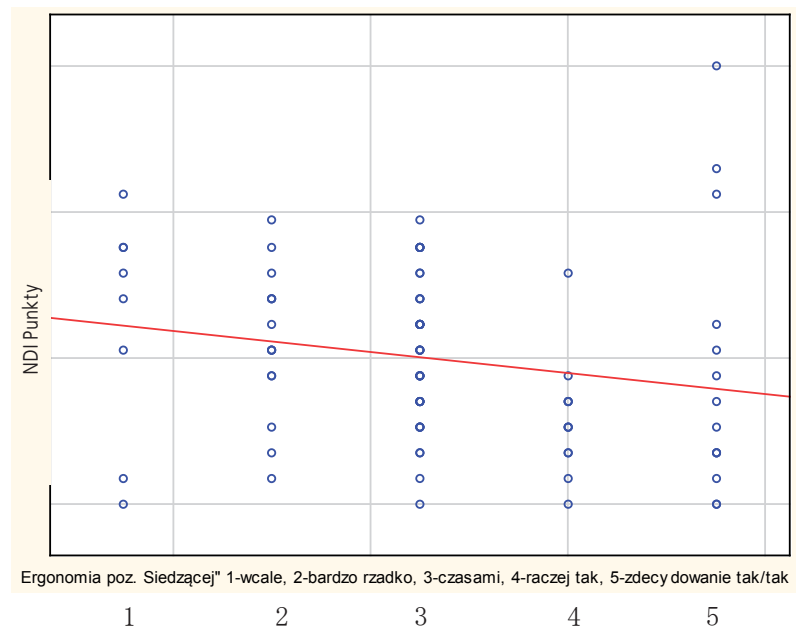

Rycina 1. Korelacja pomiędzy stosowaniem zasad ergonomii w pozycji siedzącej a punktami uzyskanymi w kwestionariuszu NDI wśród badanych 
Drugą istotną statystycznie dodatnią zależność $(r=0,527486 ; p<0,05)$ odnotowano pomiędzy częstością dolegliwości bólowych, a punktami uzyskanymi w kwestionariuszu NDI (Tabela 4, rycina 2).

Tabela 4. Wyniki korelacji pomiędzy częstością dolegliwości bólowych a punktami uzyskanymi w kwestionariuszu NDI

\begin{tabular}{|l|c|c|c|c|}
\hline \multicolumn{1}{|c|}{$\begin{array}{c}\text { Para } \\
\text { zmiennych }\end{array}$} & \multicolumn{3}{|c|}{$\begin{array}{r}\text { Korelacja porządku rang Spearmana BD usuwane parami } \\
\text { Oznaczone wsp. korelacji są istotne }\end{array}$} \\
& $\mathrm{N}$ & $\mathrm{R}$ & $\mathrm{t}(\mathrm{N}-2)$ & $\mathrm{p}$ \\
$\begin{array}{l}\text { Częstość } \\
\text { dolegliwości } \\
\text { bólowych/NDI }\end{array}$ & 88 & 0,527486 & 5,757908 & 0,000000
\end{tabular}

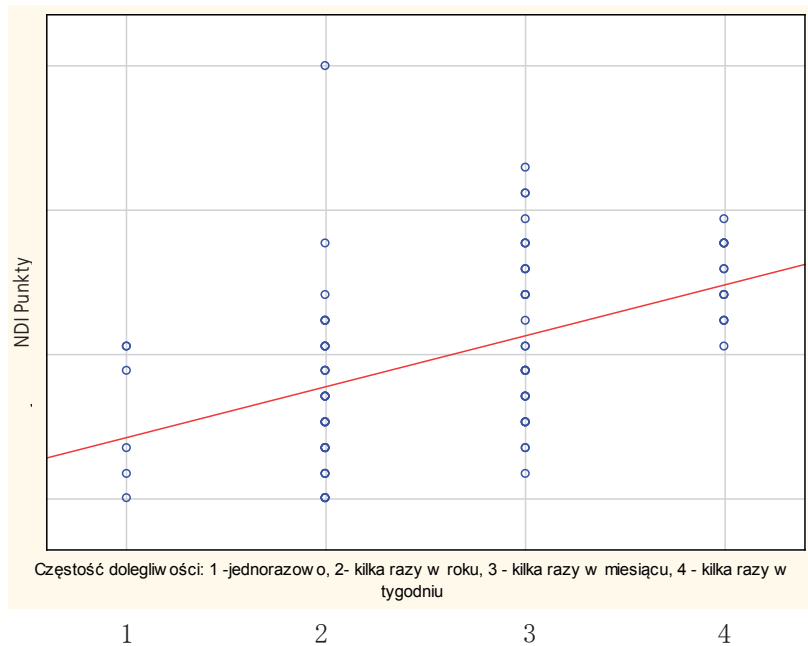

Rycina 2. Korelacja pomiędzy częstością dolegliwości bólowych a punktami uzyskanymi w kwestionariuszu NDI wśród badanych

\section{Dyskusja}

Praca w zawodzie fizjoterapeuty skupia się głównie na czynnościach wymagających fizycznej pracy w wymuszonych pozycjach ciała wykonywanych wielokrotnie w ciągu dnia, co prowadzi do powstania przeciążeń w obrębie narządu ruchu. Grupą szczególnie narażoną na wystąpienie dolegliwości bólowych kręgosłupa wynikających z przeciążeń powstałych w czasie pracy z pacjentem są studenci fizjoterapii, którzy w trakcie studiów zapoznają się i uczą poprawnej techniki wykonywania czynności fizjoterapeutycznych, z zachowaniem zasad ergonomii.

Wyniki badań niniejszej pracy ukazały, że ból odcinka szyjnego kręgosłupa stanowi poważny i powszechny problem wśród studentów fizjoterapii. Na ból szyi uskarżało się 76\% badanych i w 93\% przypadków miał on charakter przewlekły i nawrotowy. Najczęściej ból pojawiał się podczas siedzenia oraz stania. Im częściej pojawiały się bóle szyi, tym respondenci wskazywali na wyższy stopień niepełnosprawności. Znacząca liczba studentów przestrzega- ła zasad ergonomii zarówno w czynnościach dnia codziennego, jak i podczas snu, co przekładało się na uzyskanie przez nich niższych wyników w kwestionariuszu NDI.

Wyniki badań własnych korelują z wynikami innych autorów podejmujących zagadnienia dotyczące problemów bólowych kręgosłupa wśród grupy zawodowej fizjoterapeutów. W badaniach Radzimskiej i wsp., w których jako narzędzie wykorzystano Kwestionariusze Neck Disability Index (NDI) i Kwestionariusz Oswestry Disability Index (ODI) do oceny stopnia niepełnosprawności związanych odpowiednio z bólem szyi oraz bólem odcinka lędźwiowego kręgosłupa przeprowadzonych na grupie fizjoterapeutów, wykazano, że przeszło połowa klasyfikowała się do łagodnej niepełnosprawności. Odnotowano, że częściej bóle dotyczyły odcinka lędźwiowego, choć badani wskazywali na poważny problem wynikający z bólów głowy które były konsekwencją przeciążeń i dysfunkcji szyjnego odcinka kręgosłupa. W badaniach wykazano również, że wraz ze wzrostem stażu pracy i wiekiem wzrastał poziom niepełnosprawności mierzonej kwestionariuszami ODI i NDI [10]. W badaniach Czupryny i wsp. przeprowadzonych w grupie fizjoterapeutów zajmujących się metodam nerorehabilitacyjnymi również zaobserwowano, że ból w odcinku lędźwiowym występował częściej (u 48\% badanych) niż w odcinku szyjnym (u 19\% badanych) [11].

Sieradzki i wsp. objęli badaniem 110 studentów fizjoterapii, u których określano stopień niepełnosprawnośc za pomocą standaryzowanego wskaźnika sprawności w bólach dolnej części kręgosłupa - ODI (Oswestry Disability Index). Wśród badanych studentów ponad 50\% uskarżało się na dolegliwości bólowe ze strony dolnego odcinka kręgosłupa, potwierdzając, że problemy rozpoczęły się w czasie trwania studiów i zainicjowane zostały w pozycj stojącej. Mimo że badani studenci w większości posiadali wiedzę na temat działań fizjoterapeutycznych w zwalczaniu dolegliwości bólowych kręgosłupa, nie stosowali ich w przypadku własnych dysfunkcji. Badani przejawiali również niski poziom zachowań zdrowotnych, co miało odzwierciedlenie w większych doznaniach bólowych kręgosłupa [12].

W badaniach Lisińskiego i wsp. prowadzonych na grupie 70 fizjoterapeutów odnotowano bóle w obrębie lędźwiowego odcinka kręgosłupa wśród 90\% badanej grupy, a pozycja stojąca i czynności wymagające dźwigania w największym stopniu wpływały na poziom bólu. Warto dodać, że $60 \%$ badanych fizjoterapeutów zgłaszających ból kręgosłupa nie przejawiało żadnej aktywności fizycznej [13]. W badaniach lqbal i wsp. 92\% fizjoterapeutów uskarżało się na zaburzenia układu mięśniowo-szkieletowego i najczęstszą zgłaszaną lokalizacją był odcinek lędźwiowy kręgosłupa [14] 
Dolegliwości bólowe odcinka szyjnego kręgosłupa stanowią problem wśród innych zawodów medycznych. Ćwierzeń i wsp. poddali badaniom higienistki stomatologiczne. Wykazano, iż ok. 88\% badanych higienistek stomatologicznych narażonych jest na niekorzystne przeciążenia kręgosłupa [15]. Guzy i wsp. w badaniach odnotowali występowanie szyjnych zespołów bólowych wśród studiujących i pracujących zawodowo kosmetyczek, gdzie wykazano, że bóle szyi dotyczą 40\% badanych [5]. W badaniach Płonicki i wsp. odnotowano ból szyi u 71\% badanych dentystów [16].

Mikołajewska i wsp., prezentując aktualny stan wiedzy na temat dysfunkcji mięśniowo-szkieletowych wśród fizjoterapeutów, podaje, że w Polsce dotyczy to od 20\% do $90 \%$ fizjoterapeutów. Wskazuje również na potrzebę zwrócenia większej uwagi na działania prewencyjne dla osób rozpoczynających pracę w zawodzie fizjoterapeuty, a także wdrażania programów profilaktycznych dla osób zawodowo związanych z rehabilitacją, które stanowić powinny główny czynnik wpływającym na zmniejszenie dolegliwości bólowych w obrębie kręgosłupa w grupie zawodowej fizjoterapeutów [17]

\section{Wnioski}

1) Studenci fizjoterapii charakteryzują się głównie umiarkowanym poziomem aktywności fizycznej, a dolegliwości bólowe szyjnego odcinka kręgosłupa klasyfikują respondentów do grupy łagodnej niepełnosprawności według kwestionariusza NDI.

2) Niższy poziom niepełnosprawności wśród studentów fizjoterapii związany był z częstszym stosowaniem stosowania zasad ergonomii w pozycji siedzącej i rzadszymi epizodami dolegliwości bólowych szyjnego odcinka kręgosłupa.

\section{Oświadczenia}

Oświadczenie dotyczace konfliktu interesów

Autorzy deklarują brak konfliktu interesów.

Źródła finansowania

Autorzy deklarują brak źródeł finansowania.

\section{Piśmiennictwo}

1. Guzy G, Frańczuk B. Effectiveness of the McKenzie method in regard to head posture and motion of the cervical spine In patients with cervical derangement syndrome. J. Orthop. Trauma Surg 2010; (1): 29-41.

2. Bartosiewicz Z. Stan wiedzy na temat występowania i przyczyn powstawania zespołów bólowych kręgosłupa w społeczeństwie u studentów warszawskich uczelni. Post Rehabil 2012; 26 (1): 37-43
3. Matuszewska W, Tomczak H. Ocena wpływu kompleksowe fizjoterapii na poziom bólu w odcinku szyjnym kręgosłupa. Acta Balneol 2011; 53 (2): 124-132.

4. Istrati J. Przewlekły zespół bólowy kręgosłupa szyjnego - postępowanie według medycyny opartej na faktach. Ból 2011 12 (4): 15-18

5. Guzy G, Ridan T, Drożdżoł-Brzęczek A. Występowanie szyjnych zespołów bólowych wśród studiujących i pracujących zawodowo kosmetyczek. Med. Man 2014; 18 (2/3): 39-45.

6. Szymfel K, Witke-Woźniak A, Kwiatkowski K. Analiza skuteczności wybranych ćwiczeń metodą Feldenkraisa w leczeniu zespołów bólowych odcinka szyjnego kręgosłupa. Rehabil Prakt 2016; (5): 49-53.

7. Prajs K, Fliciński J, Przepiera-Będzak H. Ból karku - objawy, czynniki ryzyka, diagnostyka i postępowanie. Lekarz 2010; (3):18, 20-22.

8. Guzy G, Szpitalak M, Frańczuk B i wsp. Zależności pomiędzy czynnikami psychologicznymi a wybranymi zmiennymi wśród pacjentów z przewlekłym, szyjnym zespołem zaburzeń strukturalnych. Med Sport 2013; 29 (3): 163-173.

9. Stefanowicz A, Kloc W. Rozpowszechnienie bólu krzyża wśród studentów. Ann Med 2009; 16 (1): 28-41.

10. Radzimińska A, Weber-Rajek M, Jaworska U i wsp. Zespoły bólowe kręgosłupa w grupie fizjoterapeutów. Health and Sport 2016; 6 (6): 553-564.

11. Czupryna K, Nowotny-Czupryna O, Nowotny J. Ergonomiczne uwarunkowania zespołów bólowych kręgosłupa u fizjoterapeutów zajmujących się neurorehabilitacją dzieci. Ortop Traumatol Rehab 2014; 4(6): 407-418.

12. Sieradzki M, Krajewska-Kułak E, Van Damme-Ostapowicz K Ocena występowania zespołów bólowych dolnego odcinka kręgosłupa w populacji studentów kierunku fizjoterapia, Probl Hig Epidemiol 2013; 94 (3): 451-458.

13. Lisiński P, Samborski W. Bóle kręgosłupa lędźwiowego w grupie zawodowej fizjoterapeutów. Baln Pol 2006; 3: 156-160.

14. Iqbal Z, Alghadir A. Prevalence of work - related musculoskeletal disorders among physical therapists, Medycyna Pracy 2015; 66 (4): 459-469.

15. Ćwirzeń W, Wagner L, Piróg P. Obciążenie kręgosłupa szyjnego w praktyce zawodowej higienistki stomatologicznej. e- Dentico 2013; (6): 86-91.

16. Płocki J, Pikuła D, Banaś J i wsp. The effect of ergonomics in dentistry on the occurrence of pain in the cervical neck region of the spine. Stud Med 2015: 31 (1): 35-41.

17. Mikołajewska E. Urazy mięśniowo-szkieletowe związane z pracą u fizjoterapeutów. Medycyna Pracy 2013; 64 (5) 681-687.

Zaakceptowano do edycji: 20.08.19 Zaakceptowano do publikacji: 26.09.19

\author{
Adres do korespondencji: \\ Magdalena Rutkowska \\ Zakład Kinezyterapii i Metod Specjalnych, WNoZ w Katowicach \\ SUM w Katowicach \\ ul. Medyków 12 \\ 40-752 Katowice \\ tel. 502-181-213 \\ e-mail: mrutkowska@sum.edu.p
}

